\title{
Hypoglycaemic Mechanism of Manosrin from Anisopus Mannii N. E. Br.
}

\author{
Zaruwa MZ1*, Manosroi J22, Akihisa T² and Manosroi A $^{2}$ \\ 1Department of Biochemistry, Adamawa State University, Nigeria \\ ${ }^{2}$ Faculty of Pharmacy, Chiang Mai University, Thailand \\ ${ }^{3}$ School of Chemical Engineering, Nihon University, Japan
}

\section{Research article}

Volume 3 Issue 3

Received Date: May 21, 2018

Published Date: June 06, 2018

*Corresponding author: Zaruwa MZ, Department of Biochemistry, Adamawa State University, Mubi, Nigeria, Tel: +234 814395 0001; Email: moseszira@gmail.com

\section{Abstract}

Medicinal Plants from various parts of the world have been tested for their hypoglycaemic properties and other related ailments. These have resulted into the isolation and purification of novel compounds which have been made into drugs and commercialized. The MeOH sub-fraction of Anisopus mannii N. E. Br.yielded 'Manosrin' (3, 23, 28 Trihydroxy-12oleanen-3-0-( $\beta$-D-glucopyranosyl-(1,6)- $\beta$-D-glucopyranosyl(1,6)- $\beta$-D-xylopyranosyl)-28-O- $\beta$-D-glucopyranosyl-(1,6)- $\beta$ D-glucopyranoside) as a novel compound. To understand the mechanism of the drug action using ICR mice and other possible effect of the drug as hypoglycaemic compound. Manosrin was subjected to evaluations, such as oral glucose tolerance test (OGTT), standard toxicity studies, pathological investigations and route of efficiency, by intraperitoneal injection and oral administration using ICR mice, and the drug mechanism of action by co-treatment with isosorbide dinitrate and nifedipine as $\mathrm{Ca}^{+}$and $\mathrm{K}^{+}$ion channel regulators. Oral administration of the methanol sub-fraction $(250$ $\mathrm{mg} / \mathrm{kg} \mathrm{bw}$ ) inhibited blood glucose increase, but stimulated blood glucose lowering in post prandial ICR mice. Significant body weight gains were observed both in the 2,000 and $5,000 \mathrm{mg} / \mathrm{kg}$ bw treated groups at day 3 to 14 .All of the treated groups showed significant $(\mathrm{P}<0.05)$ decrease in organ weights compared to the control group (kidney and liver). The BUN and creatinine levels decreased in Manosrin treated groups in the 2,000 and 5,000 mg/kg bw treated groups. However, a dose dependent elevation was observed for AST, ALT and Total bilirubin levels. The oral and intraperitoneal administration of Manosrin showed higher efficiency than Glibenclamide but lower than insulin. The co-treatment of ICR mice with ion channel regulators, showed that Manosrin was not dependent on the closure of $\mathrm{K}^{+}$and opening of the $\mathrm{Ca}^{2+}$ channels. It could therefore be speculated that Manosrin may have enhanced insulin activity as a way of FBG reduction in the diabetic mice. Manosrin has exhibited a Thiazolidinedione-like action as its modus operandi. The hypoglycaemic effect observed prompts further investigation on other possible potentials of this compound in the management of Diabetes mellitus and related diseases.

Keywords: Manosrin; Hypoglycaemic; Isosobide dinitrate; Nifedipine; Ion channel 


\section{International Journal of Biochemistry \& Physiology}

Abbreviations: DM: Diabetes mellitus; OGTT: Oral Glucose Tolerance Test; FBG: Fasting Blood Glucose; BUN: Blood Urea Nitrogen.

\section{Introduction}

Diabetes mellitus (DM) is a complex disease linked with a condition of high glucose level in the blood, or hyperglycaemia, resulting from deficiencies in the amount of insulin secretion, inaction, or both. Diabetic patients thus suffer from complications of macro- and micro vascular tissues, which if not properly managed, lead to frequent hospitalization and complications, together with increased risk of cardiovascular diseases [1].

Diabetes mellitus is a condition which afflicts approximately 387 million people across the globe [2]. The Centre for Disease Control and Prevention about 86 million people had prediabetes condition and $15-30 \%$ of them developed into full-blown diabetes [3]. The African story of Diabetes mellitus is that of ignorance and poverty. As the ailment spreads due to these factors, several researchers have subjected alternative therapies linked to different communities in and around Africa, South America and Asia [4]. Amidst must of these researches on traditional Medicinal plants or remedies, little is talked of concerning the mechanism of action for the potent hypoglycaemic remedies. Where these are discussed, the conclusions are usually postulations based on plausible assumptions.

This research is aimed at investigating one of such results of a potent hypoglycaemic compound from an African traditional medicinal plants Anisopus mannii N. E. Br. [5]. The new compound of interest called 'Manosrin' $(3, \quad 23, \quad 28-T r i h y d r o x y-12-$ oleanen-3-0- $(\beta-D-$ glucopyranosyl-(1,6)- $\beta$-D-glucopyranosyl- $(1,6)-\beta$-Dxylopyranosyl)-28-0- $\beta$-D-glucopyranosyl-(1,6)- $\beta$-Dglucopyranoside). The new compound though still at the infancy stage showed highly potent hypoglycaemic effect on mice [6]. This research strives to evaluate certain parameters like free radical scavenging activity of the crude extract, Oral glucose tolerance test (OGTT), acute oral toxicity studies and other methods towards the understanding of the compound's mechanism of action, and the pathological studies of the hypoglycaemic compound.

\section{Materials and Methods}

\section{Experimental Animals}

Adult male and female ICR mice weighing between 24 27 g purchased from the Faculty of Medicine, Chiang Mai University and the National Laboratory Animal Center-
Mahidol University, Thailand, were used. The mice were fed with the standard diet, water ad libitum and were maintained under the standard conditions of temperature, humidity and light $\left(23 \pm 1^{\circ} \mathrm{C} ; 70 \% \mathrm{RH}\right.$ and $12 \mathrm{~h}$ light/dark). The experiments was complied with the Organization for Economic Co-operation and Development (OECD/OCDE: 425) Guidelines for Testing of Chemicals [7].

\section{Production of the Diabetic Mice}

Diabetic mice were produced as previously described by Zhou, et al. [8]. Briefly, the mice were injected at the tail vein with alloxan monohydrate in sterile normal saline solution at the dose of $75 \mathrm{mg} / \mathrm{kg}$ bw. Diabetes was confirmed on the third day after alloxan administration. The mice having blood glucose levels greater than 200 $\mathrm{mg} / \mathrm{dl}$ were considered diabetic and selected for further study [9]. Fasting Blood Glucose (FBG) was assayed from the tail vein blood of the mice using Finetest Glucometer (Infopia Co., Ltd. Korea). Three doses of the plants extract $\left(100,200\right.$ and $\left.400 \mathrm{mg} \mathrm{kg}^{-1} \mathrm{bw}\right)$ [10] were orally administered to the $18 \mathrm{~h}$ fasted normal/diabetic mice ( $\mathrm{n}=$ 5) using feeding tube [11]. Noticeable irritation or restlessness should not be observed after administration of the extracts. Blood glucose was measured hourly for 4 hrs. Control mice were fed with distilled water (oral), whereas insulin $0.5 \mathrm{IU} / \mathrm{kg}$ (injection/ip) and glibenclamide $1 \mathrm{mg} / \mathrm{kg}$ (oral) were used as reference hypoglycemic drugs.

\section{Hypoglycaemic Compound (Manosrin)}

The compound Manosrin was obtained from Anisopus mannii $\mathrm{N}$. E. Br. according to the method described by Zaruwa, et al. [6].

\section{Oral Glucose Tolerance Test (OGTT)}

OGTT was performed by using the modified methods as described by $\mathrm{Wu}$, et al. [12]. Briefly, normoglycemic mice were divided into five groups of 5 mice each. The mice were fasted for $18 \mathrm{~h}$, and then treated with the agent orally using a feeding tube. After two hours, DW or different carbohydrates were administered as indicated; glucose (2.5 g/kg, o.p.), Sucrose (2.5 g/kg, o.p.), Corn starch $(6 \mathrm{~g} / \mathrm{kg}$, o.p.) and lactose $(6 \mathrm{~g} / \mathrm{kg}$, o.p). The blood glucose were tested at $0,1,2,3$ and $4 \mathrm{~h}$. Glibenclamide (Glb - $1.0 \mathrm{mg} / \mathrm{kg} \mathrm{bw}$ ) and Insulin (Ins - $0.5 \mathrm{iu} / \mathrm{kg} \mathrm{bw}$ ) served as control (1 mg/kg bw, o.p.).

\section{Co-treatment with $\mathrm{Ca}^{+}$and $\mathrm{K}^{+}$ion Channel Regulators}

Normoglycemic mice were divided into four groups $(n=5)$ with three other groups treated with $\mathrm{Ca}^{+}$ 


\section{International Journal of Biochemistry \& Physiology}

(Nifedipine) or $\mathrm{K}^{+}$(Isosorbate dinitrate) channel regulators (Wu et al., 2010). The NC group was treated with normal saline (i.p.), AMS (250 mg/kg bw + normal saline, i.p.), AMN (250 mg/kg bw + normal saline + Nifedipine $13.6 \mathrm{mg} / \mathrm{kg}$, o.p.) and AMI (250 mg/kg bw + normal saline + Isosorbide dinitrate $6.8 \mathrm{mg} / \mathrm{kg} \mathrm{bw}$ respectively. Blood glucose was tested at $0,2,4$ and $6 \mathrm{~h}$ post treatment.

\section{Intraperitoneal Injection and Oral Administration Studies}

Mice were kept under standard conditions of temperature and humidity. The animals were fasted for 18 hours and $75 \mathrm{mg} / \mathrm{kg}$ bw alloxan monohydrate administered via the tail vein. Diabetic mice $(<200 \mathrm{mg} / \mathrm{kg}$ bw) were selected and grouped into three $(n=5)$. To the control group was administered distilled water (DW), group 1 received AM (62.5 mg/kg bw, i.p.) and group 2 received AM (250 mg/kg bw, o.p.). Blood glucose was monitored at $0,1,2,3$ and 4 h post treatment.

\section{Acute Oral Toxicity Studies}

The acute oral toxicity study was done with modified protocol as described by Adeneye, et al. [13]. Manosrin was prepared using $2 \mathrm{ml}$ normal saline solution and administered sequentially over a $12 \mathrm{~h}$ period using a feeding tube. Studies were conducted using the limit test of up and down procedure according to the OECD/OCDE Test Guidelines [7]. A total of five female mice were selected at random. The mice were fasted for $18 \mathrm{~h}$. Body weight of each mouse was determined and dosed with equivalent of $2000 \mathrm{mg} / \mathrm{kg}$ bw (because no lethal effect was expected since the medicine has been in use among humans) of the $\mathrm{MeOH}$ sub-fraction dissolved in distilled water using a feeding tube. Mortalities, clinical signs, body weight changes and gross findings were monitored for 14 days $(1-15)[14]$.

Each animal was observed each time for the first 10 min post dosing for signs of regurgitation and thereafter for every $30 \mathrm{~min}$ for the successive $6 \mathrm{~h}$ and daily for 14 days for possible lethal outcome. Behavioral manifestations of acute oral toxicity were also noted for each mouse. The same procedure was repeated with 5000 $\mathrm{mg} / \mathrm{kg}$ bw of the Manosrin on different groups of mice.

\section{Experimental Execution/Histopathological Examination}

All mice were observed for 14 days and their body weights taken every $72 \mathrm{~h}$. On the 14 th day, each mouse was decapitated with a shape surgical blade and blood collected in clean appendorf tubes and centrifuged at $3000 \mathrm{rpm}$ for 10 minutes. Sera were collected for each mouse in an appendorf tube, labelled and stored at $4^{\circ} \mathrm{C}$, to be used for blood urea nitrogen (BUN), Creatinine, AST, ALT and total bilirubin analyses. The kidney and liver were removed, washed in normal saline, wiped and weighed on a digital balance and preserved in 10\% formalin for histopathology examination.

In the histopathological examination, the kidney and liver of mice from the three groups were embedded in paraffin, cut into 6 and $12 \mu \mathrm{m}$ thick, respectively. They were later stained with haematoxylin and eosin and examined under a light microscope [15].

\section{Ethical Clearance}

The animal experimental methods were approved by Chiang Mai University Animal Ethics Committee, Protocol Number: 40/2552.

\section{Statistical Analysis}

The data are expressed as mean \pm SEM or mean \pm SD calculated from Microsoft excel 2003. Differences between 2 means were compared using student's t- test. Values were considered statistically significant at $\mathrm{p}<$ 0.05 .

\section{Results and Discussion}

\section{Modified Oral Glucose Tolerance Test}

The hypoglycaemic effects of Manosrin in post-prandial hyperglycaemia in normal mice treated with various carbohydrates are shown in Figure 1. DW: distilled water, Cst: corn starch, Glu: glucose, Suc: sucrose, Lac: lactose, AM: Manosrin, Glib: Glibenclamide, Ins: insulin, PPBG: postprandial blood glucose. The test was performed by feeding the mice with various carbohydrates. The carbohydrates were given $2 \mathrm{~h}$ after being fed with Manosrin $(250 \mathrm{mg} / \mathrm{kg} \mathrm{bw})$ or Glibenclamide $(1.00 \mathrm{mg} / \mathrm{kg}$ bw).

a) Manosrin was ineffective on the PPBG levels in corn starch fed group.

b) Manosrin effectively reduced the PPBG levels in glucose fed group.

c)Manosrin was ineffective on the PPBG level in the sucrose fed group.

d) Manosrin effectively reduced the PPBG levels in the lactose fed group $(* \mathrm{p}<0.05)$. 


\section{International Journal of Biochemistry \& Physiology}

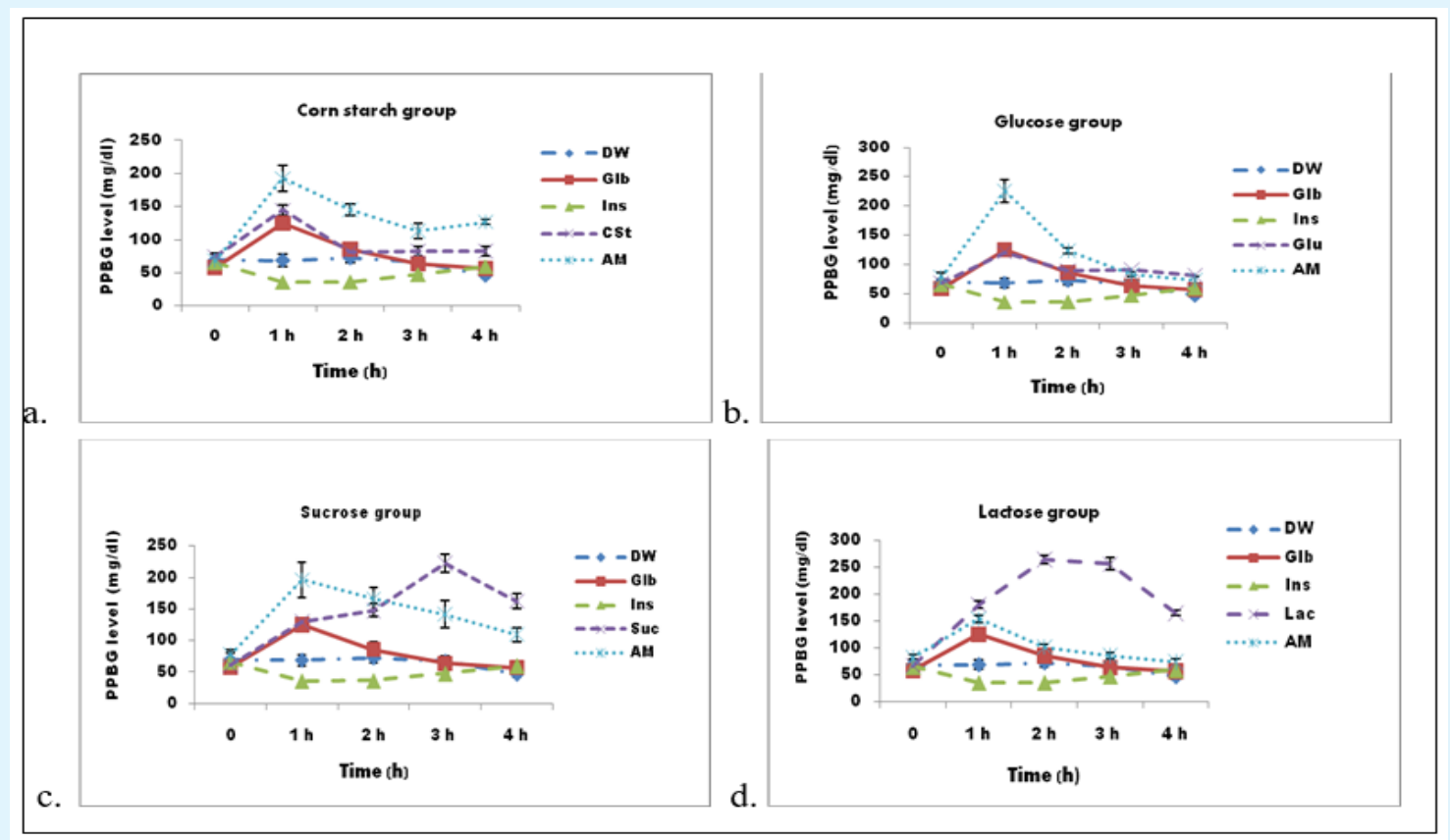

Glb: Glibenclamide, CS: Corn starch, Glu: Glucose, Suc: Sucrose, Lac: Lactose, PPBG: Post Prandial Blood Glucose. Figure 1: Hypoglycaemic effects of Manosrin on postprandial glucose (PPBG) levels of normal mice with various carbohydrates. Oral administration of the methanol sub-fraction $(250 \mathrm{mg} / \mathrm{kg} \mathrm{bw})$ inhibited the increase, but stimulated the blood glucose decrease in post prandial glucose (Figures 1a - 1d).

\section{Effect of Oral and Intraperitoneal Manosrin showed similar effect.} Administration of Manosrin

Both oral and intraperitoneal administration of the

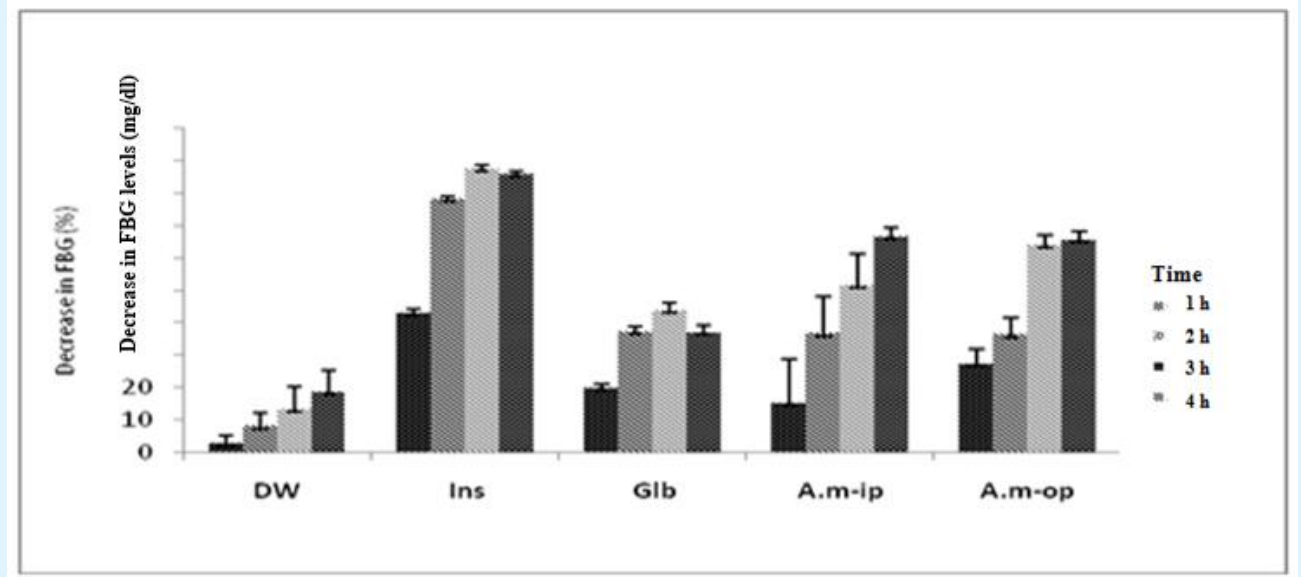

Figure 2: Effects of oral and intraperitoneal administration of the Manosrin (62.5 or $120 \mathrm{mg} / \mathrm{kg}$ ) on FBG compared with insulin $(0.5 \mathrm{I} . \mathrm{U} / \mathrm{kg}$ bw-ip) and Glibenclamide $(1.0 \mathrm{mg} / \mathrm{kg} \mathrm{bw}-o p)$ in diabetic mice. DW: distilled water, Ins: Insulin, Glb: Glibenclamide, A.m-ip: Manosrin-itraperitoneal, A.m-op: Manosrin-per oral hypoglycemic effects. The hypoglycaemic effect of a single dose of Manosrin $(62.5 \mathrm{mg} / \mathrm{kg}$ bw, ip and $120 \mathrm{mg} / \mathrm{kg} \mathrm{bw}$, po) were compared to the standard drugs (insulin - $0.5 \mathrm{iu} / \mathrm{kg}$ bw by iv and Glibenclamide $1.0 \mathrm{mg} / \mathrm{kg}$ bw by po). The Manosrin showed higher efficiency than Glibenclamide, but lower than insulin. 


\section{International Journal of Biochemistry \& Physiology}

\section{Effects of Calcium (Nifedipine) and Potassium (Isosorbide) Channel Regulators on Hypoglycaemic Activity of Manosrin}

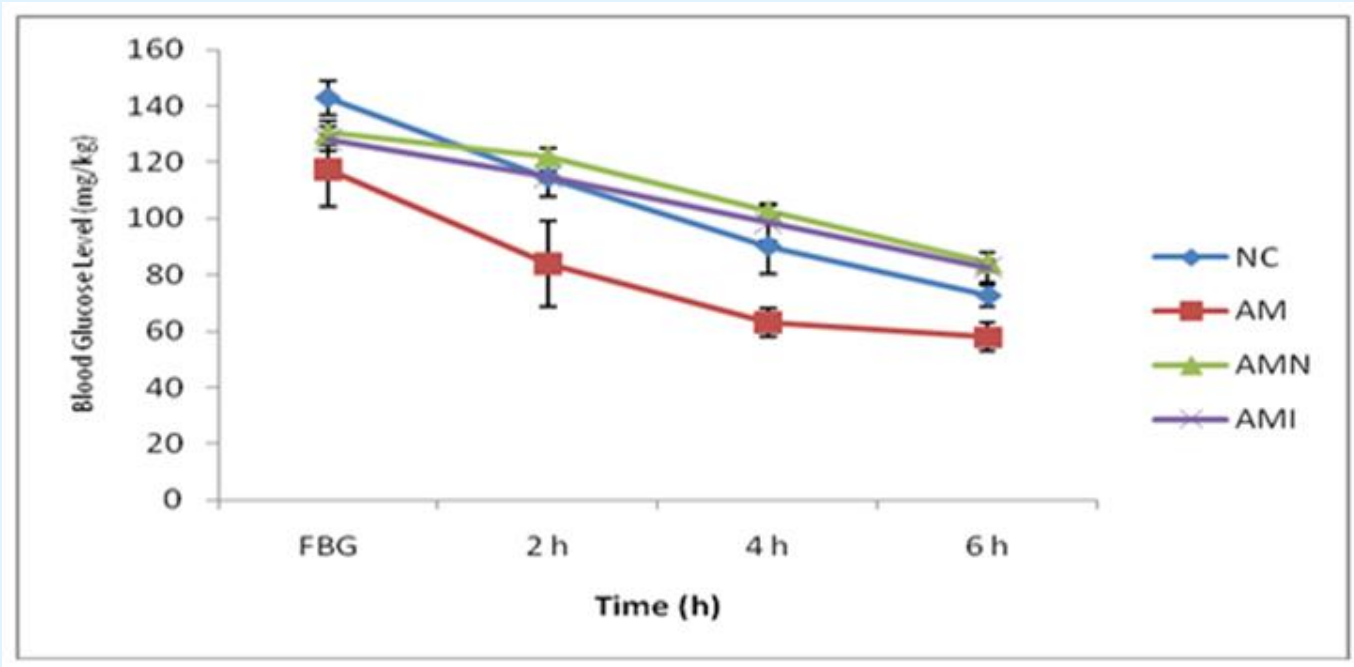

Figure 3: Effects of calcium (nifedipine) and potassium (isosorbide) channel regulators on hypoglycaemic activity of Manosrin in normal mice. NC, normal control treated with distilled water only, AM: treated with Manosrin at 250 $\mathrm{mg} / \mathrm{kg}$ ip, AMN: treated with the Manosrin at $250 \mathrm{mg} / \mathrm{kg}$ ip plus nifedipine (13.6 mg/kg, o.p.). AMI: treated with the Manosrin (250 mg/kg ip) plus isosorbide dinitrate (6.8 mg/kg, o.p.).

${ }^{*} \mathrm{p}<0.05$ vs. NC group. AM: Manosrin, AMN: Manosrin/Nifedipine, AMI: Manosrin/Isosorbidide dinitrate, NC: Normal control

\section{Mean Body Weights $(\mathrm{g})$ of Mice $(n=5)$ at 14 days after Treated with Manosrin}

The body and organ weights of mice treated with Manosrin at the doses of 2,000 and 5,000 mg/kg bw are shown in Tables 1 and 2. There were no animal deaths in the former group. Significant body weight gains were observed both in the 2,000 and 5,000 mg/kg bw treated groups at day 3 to 14 . The relative body weights in the
$2,000 \mathrm{mg} / \mathrm{kg}$ bw group were surprisingly higher than those in the $5,000 \mathrm{mg} / \mathrm{kg}$ bw group. The body weight gains were attributed to the effect of Manosrin. The mean \pm SEM of kidney and liver weights with their relative organ weights compared to the body weights are shown in Table 2. Relative weight gains were observed for all the organs when compared to the untreated group.

\begin{tabular}{|c|c|c|c|}
\hline \multirow{2}{*}{ Day } & \multirow{2}{*}{ Control } & \multicolumn{2}{|c|}{ Mean body Weight (me: $\mathbf{\pm S E M}$} \\
\cline { 3 - 4 } & $24.20 \pm 0.86$ & $\mathbf{2 , 0 0 0} \mathbf{~ m g} / \mathbf{k g}$ & $\mathbf{5 , 0 0 0} \mathbf{~ m g} / \mathbf{k g}$ \\
\hline 0 & $23.40 \pm 0.88$ & $23.40 \pm 0.52$ & $24.40 \pm 0.66$ \\
\hline 3 & $24.20 \pm 0.63$ & $24.80 \pm 0.26^{*_{a}}$ & $24.80 \pm 0.26$ \\
\hline 6 & $24.60 \pm 0.52$ & $24.60 \pm 0.32^{*_{a}}$ & $25.20 \pm 0.63^{*_{a}}$ \\
\hline 9 & $24.20 \pm 0.48$ & $25.20 \pm 0.26^{* a}$ & $25.60 \pm 0.52^{* a}$ \\
\hline 12 & $25.20 \pm 0.26$ & $24.80 \pm 0.26^{* a}$ & $25.80 \pm 0.63^{* a}$ \\
\hline 14 & $25.40 \pm 0.32^{\text {a }}$ & $26.00 \pm 0.58^{* a}$ \\
\hline
\end{tabular}

Table 1: Mean body weights (g) of mice ( $\mathrm{n}=5$ ) at 14 days after being treated with Manosrin at the doses of 2,000 and $5,000 \mathrm{mg} / \mathrm{kg}$ bw.

*Significant difference from the control, $\mathrm{p}<0.05$. a Significant difference from day $0-14, \mathrm{p}<0.05$. Each group was Treated with Manosrin and normal saline sequentially in the first day and observed the body weights for 14 days. 


\section{International Journal of Biochemistry \& Physiology}

\begin{tabular}{|c|c|c|c|c|c|c|}
\hline \multirow{2}{*}{ Organ } & \multicolumn{2}{|c|}{ Control } & \multicolumn{4}{c|}{ Fraction of $\boldsymbol{A}$. mannii (M) } \\
\cline { 2 - 7 } & Entreated & RW (\%) & $\mathbf{2 0 0 0} \mathbf{( m g )}$ & RW (\%) & $\mathbf{5 0 0 0} \mathbf{( m g )}$ & RW (\%) \\
\hline Kidney & $0.3925 \pm 0.02$ & $1.5699 \pm 0.09$ & $0.3306 \pm 0.04^{*}$ & $1.3223 \pm 0.17^{*}$ & $0.3484 \pm 0.01^{*}$ & $1.3937 \pm 0.03$ \\
\hline Liver & $1.4778 \pm 0.06$ & $5.9113 \pm 0.24$ & $1.3379 \pm 0.06^{*}$ & $5.32517 \pm 0.23^{*}$ & $1.3750 \pm 0.01^{*}$ & $5.50 \pm 0.02^{*}$ \\
\hline
\end{tabular}

Table 2: Mean organ weights (g) of mice $(n=5)$ at 14 days after being treated with the Manosrinat doses of 2,000 and $5,000 \mathrm{mg} / \mathrm{kg} \mathrm{bw}$.

*Significant difference from the control, p<0.05. RW: Relative weight = organ weight/body weight $\mathrm{x} 100$

\section{Liver and Kidney Function Tests of the ICR Mice treated with 2000 and $5000 \mathrm{mg} / \mathrm{kg}$ bw of Manosrin}

All of the treated groups showed significant $(\mathrm{P}<0.05)$ decrease in organ weights in compared to the control group.
The BUN and creatinine levels decreased in Manosrin treated groups in the 2,000 and $5,000 \mathrm{mg} / \mathrm{kg}$ bw treated (Figures $4 \mathrm{a}$ and $\mathrm{b}$ ). However, a dose dependent elevation was observed for AST, ALT and Total bilirubin levels.

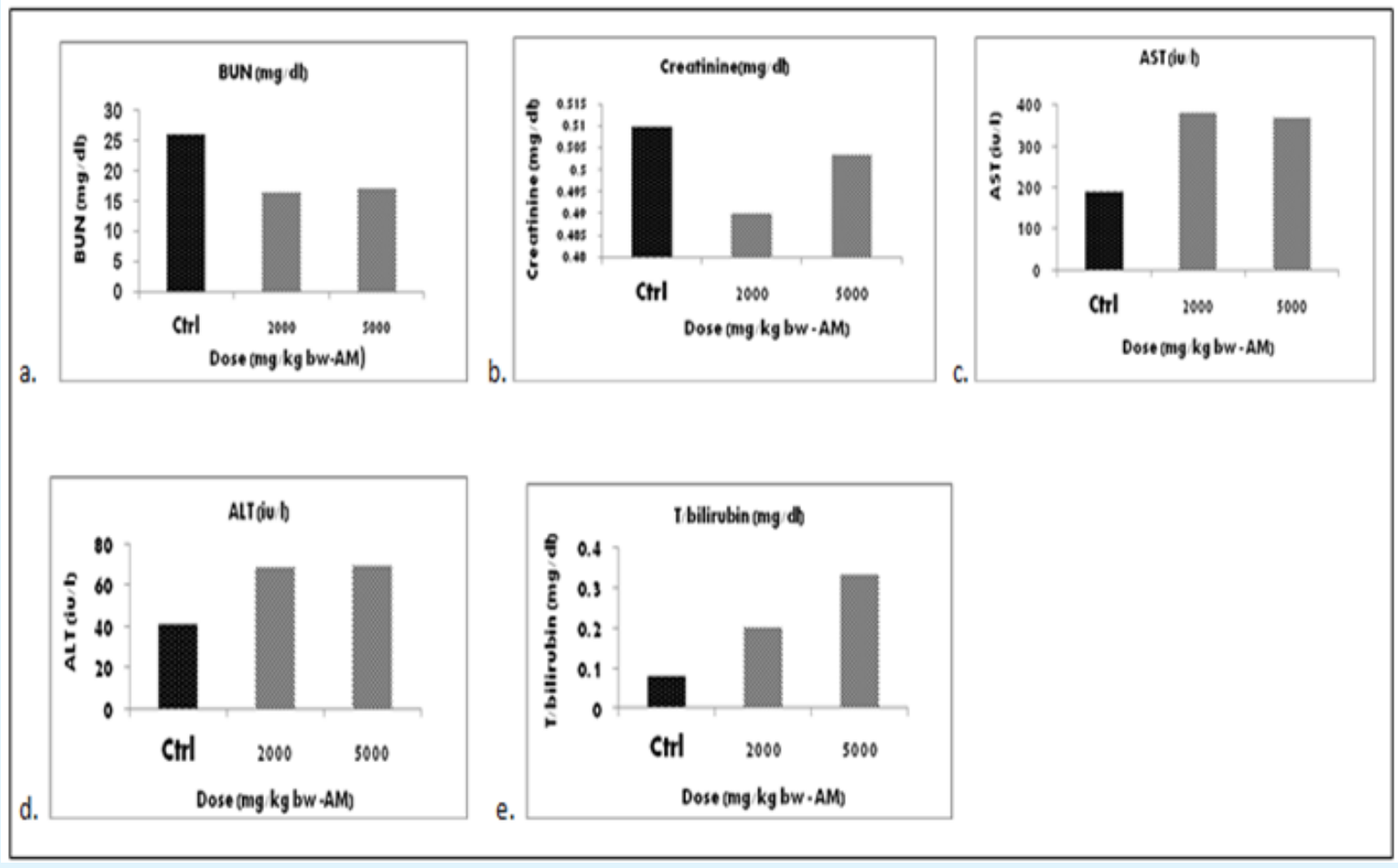

Figure 4: Liver and kidney function tests of the ICR mice fed with 2000 and $5000 \mathrm{mg} / \mathrm{kg}$ bw of Manosrin in ICR mice. a). BUN levels, b). Creatinine levels c). AST levels, d). ALT levels and e). T/bilirubin levels. BUN: Blood Urea Nitrogen, AST: Aspartate transaminase, ALT: Alanine transaminase, T/bilirubin: Total Bilirubin.

In the OGTT with Manosrin in normoglycaemic mice, the blood glucose levels were significantly $(\mathrm{p}<0.05)$ reduced to normal levels similar to those of the standard with the aid of the natural enzymes in healthy animals (Figure 1a). Usually, in the successful OGTT, the FBG levels are suppressed at the second hour [16]. This phenomenon was observed in the glucose and lactose group which implied that, Manosrin may possess glucose oxidase and lactase ( $\beta$-galactosidase) inhibition activity. A single dose treatment of Manosrin (ip or po) was able to decrease FBG levels at similar rates, thus, Manosrin showed efficiency in both fasting and postprandial states, which lead to the conclusion that Manosrin may have acted on the beta cells of the pancreas to stimulate insulin 


\section{International Journal of Biochemistry \& Physiology}

secretion and also enhanced insulin sensitivity by the cells [4].

Both oral and intraperitoneal administration of Manosrin showed similar outcome when administered orally or by intraperitoneal routes (Figure 2). The effect of a single dose of Manosrin (62.5 mg/kg bw and $120 \mathrm{mg} / \mathrm{kg}$ bw) were comparable with the standard drugs insulin ( $0.5 \mathrm{iu} / \mathrm{kg}$ bw- iv) and Glibenclamide (1.0 mg/kg bw- po). Manosrin treated mice showed higher efficiency in blood sugar reduction, than Glibenclamide, but lower than insulin (Figure 3).

It was previously reported that glucose stimulates insulin secretion via $\mathrm{K}^{+}$ATP channel pathway $[17,18]$ by closure of the cell surface ATP- sensitive $\mathrm{K}^{+}$channels and the resulting opening of cell-surface voltage-dependent $\mathrm{Ca}^{2+}$ which facilitates the extracellular $\mathrm{Ca}^{2+}$ influx into beta cells and triggers the exocytosis of insulin [12]. This phenomenon was supported by the hypoglycaemic effect of Manosrin, which was observed in mice co-treated with isosorbide dinitrate and nifedipine. It indicated that, the hypoglycaemic activity shown by Manosrin was not dependent on the closure of $\mathrm{K}^{+}$and opening of the $\mathrm{Ca}^{2+}$ channels. It could therefore be speculated that Manosrin may have enhanced insulin activity as a way of FBG reduction in the diabetic mice (Figure 3 ).

In the acute toxicity studies with Manosrin, no sign of behavioural changes, toxic signs as shown by the normal appearance of respiration pattern, colour of body surface, frequency of movement both voluntary and involuntary were observed. However, both body and organ weights were significantly ( $\mathrm{p}<0.05$ ) altered (Tables 1\&2). Surprisingly, weight gains were higher in the mice treated with Manosrin of 2,000 $\mathrm{mg} / \mathrm{kg}$ bw (6.7\%) dosage than in $5,000 \mathrm{mg} / \mathrm{kg}$ bw (4.4\%) group. A similar characteristic was also reported by Sani, et al., [19]. Evidences of likely impaired glomerular function were observed by the alteration of BUN and creatinine in the serum (Figure $4 \mathrm{a}$ and $4 \mathrm{~b}$ ). However, a reduction in serum level of blood urea could indicate that Manosrin may be tolerable to the body as observed with other medicinal plant extracts such as Bridelia ferruginea [20]. It was assumed therefore that, the kidney was able to clear the waste products from the blood. The elevation of AST and ALT in Manosrin treated mice may be an indication of temporary liver dysfunction. The increased levels were possibly due to the leakage of these enzymes from the liver cytosol or other organs into the blood stream. The results concurs with the observation of Singh, et al. [21], that the administration of some medicinal plant extracts resulted in the elevated levels of AST and ALT in the animal serum. On the other hand, the severe elevation of bilirubin by $50 \%$ or $75 \%$ in the treated groups was probably as a result of the excess destruction of haemoglobin or that the liver was not actively treating the haemoglobin it received [22]. The histopathological results however did not show any damage to the cells (not shown), which lead to the conclusion that the abnormality observed in AST, ALT and total bilirubin may be from some undiscovered factors, probably some other phytochemical substances [23]. These were characterized by a reduction in the animal's body and organ weights $[15,24]$. The significant $(\mathrm{p}<0.05)$ increase in body weight, however was probably due to the effect of Manosrin on anti-diuretic hormone resulting in fluid retention similar to other medicinal plants [25]. It was possible that, since the traditional herbalists understood polydipsia and polyuria as symptoms of Diabetes Mellitus [1], this characteristic (fluid retention) was exploited for reducing the craving for water (taste) and polyuria, while it enhanced insulin secretion for the metabolic utilization of the blood glucose.

\section{Conclusion}

The emergence of Manosrin (3, 23, 28-Trihydroxy-12oleanen-3-0-( $\beta$-D-glucopyranosyl- $(1,6)-\beta-D-$

glucopyranosyl-(1,6)- $\beta$-D-xylopyranosyl)-28-0- $\beta$-D-

glucopyranosyl-(1,6)- $\beta$-D-glucopyranoside) from Anisopus mannii N. E. Br. as apotent hypoglycaemic compound give credence to the assumption that, hypoglycaemic medicinal plants and remedies which serve as folk medicine in North-Eastern Nigeria, are indeed credible for the management of Diabetes mellitus. Though the safety studies were good, the mechanistic studies being preliminary showed a Thiazolidinedionelike action. The hypoglycaemic effect observed from Manosrin prompts further investigation on the possible potentials of this compound in the management of Diabetes mellitus and related diseases.

\section{References}

1. Kharroubi AT, Darwish HM (2015) Diabetes mellitus: The epidemic of the century. World J Diabetes 6(6): 850-867.

2. Fasanmade OA, Dagogo-Jack S (2015) Diabetes Care in Nigeria. Ann Glob Health 81(6): 821-829.

3. McCain J (2016) Prediabetes: Pre- Does Not Mean Preordained. Review. Managed Care, pp: 35-41.

4. Manosroi J, Zaruwa MZ, Manosroi A (2011) Potent hypoglycemic effect of Nigerian anti-diabetic medicinal plants. J Complement Integr Med 8(1): 116. 


\section{International Journal of Biochemistry \& Physiology}

5. Zaruwa MZ, Manosroi A, Akihisa T, Manosroi W, Rangdaeng S, et al. (2013) Hypoglycemic activity of Anisopus mannii methanolic leaf extract in normal and alloxan induced diabetic mice. J Complement Integr Med 10(1): 1-10.

6. Zaruwa MZ (2011) Hypoglycaemic activity of Thai and Nigerian Medicinal Plants. A Doctoral Thesis submitted to the Faculty of Pharmacy, Chiang Mai University, Chiang Mai, Thailand.

7. OECD (2000) Guidance Document on Acute Oral Toxicity. Environmental Health and Safety Monograph Series on Testing and Assessment No 24.

8. Zhou T, Luo D, Li X, Luo Y (2009) Hypoglycemic and hypolipidaemic effects of flavonoids from lotus (Nulumbo nuficera Gaertn) leaf in diabetic mice. Journal of Medicinal Plant Research 3(4): 290-293.

9. Cunha WR, Arantes GM, Ferreira DS, Lucarini R, Silva ML. et al. (2008) Hypoglycemic effect of Leandra lacunosa in Normal and alloxan- induced diabetic rats. Fitoterapia 79(5): 356-360.

10. Tanko Y, Yerima M, Mahdi MA, Yaro AH, Musa KY, et al. (2008) Hypoglycemic activity of methanolic stem bark of Adansonnia digitata extract on blood glucose levels of streptozotocin induced diabetic Wistar rats. International Journal of Applied Research in National Product 1(2): 33-36.

11. Moufid A (2009) Mechanistic study of antidiabetic effect of Chamaemelum nobile in diabetic mice. Advances in Phytotherapy Research (Res. Signpost) $37 / 661(2)$.

12. Wu C, Li Y, Chen Y, Lao X, Sheng L, et al. (2011) Hypoglycemic effect of Belacanda chinensis leaf extract in normal and STZ-induced diabetic rats and its potential active fraction. Phytomedicine 18(4): 292- 297.

13. Adeneye AA, Ajagbonna OP, Adeleke TI, Bello SO (2006) Preliminary toxicity and phytochemical studies of the stem bark of Musanga cecropiodes in rats. J Ethnopharmacol 105(3): 374-379.

14. Ha YW, Na YC, Seo JJ, Kim SN, Linhardt RJ, et al. (2006) Quanlitative and quantitative determination of ten major saponins in Platycodi Radix by HPLC with ELSD and MS J Chromatogr A 1135(1): 27-35.

15. Huo Y, Winters WD, Yao DL (2003) Prevention of diet-induced type 2 diabetes in C57BL/6J mouse model by an anti-diabetic herbal formulation. Phytother Res17(1): 48-55.

16. World Health Organization (1999) Definition, Diagnosis and Classification of Diabetes Mellitus and its Complications. Report of WHO consultation. Department of Non-communicable Disease Surveillance. Geneva, Switzerland.

17. Yang G, Wu L, Jiang B, Yang W, Qi J, et al. (2008) $\mathrm{H}_{2} \mathrm{~S}$ as a physiologic vasorelaxant: hypertension in Smice with deletion of cystathionine gamma-lyase. Science 322(5901): 587-590.

18. Seghers V, Nakazaki M, DeMayo F, Aguilar-Bryan L, Bryan J (2000) Sur 1 knockout mice. A model for K (ATP) channel-independent regulation of insulin secretion. J Biol Chem 275(13): 9270-9277.

19. Sani D, Sani S, Ngulde SI (2009) Phytochemical and microbial screening of the stem aqueous extract of Anisopus mannii. Journal of Medicinal Plant Research 3(3): 112-115.

20. Kolawole OM, Sunmonu TO (2010) Effect of wastewater treated with methanolic bark extract of Bridelia ferruginea Benth on rat kidney and liver. Journal of Applied Sciences and Environmental Sanitation 5: 55-64.

21. Singh A, Duggal S, Suttee A (2009) Acanthus ilicifolius Linn. - Lesser Known Medicinal Plants with Significant Pharmacological Activities. International Journal of Phytomedicine 1(1): 1-3.

22. Tietz NW, Burtis CA (2000) Fundamentals of Clinical Chemistry. $6^{\text {th }}$ (Edn.), Weekly 49(32): 729-731. 11.

23. Pereira PS, Franca SC, Olivera PVA, Breves CMS, Pereira SIV, et al. (2008) Chemical constituents from Tabernaemontana catharinensis root bark: a brief NMR review of indole alkaloids and in vitro cytotoxicity. Quim Nova 31(1): 20-24.

24. Jahn AI, Gunzel PK (1997) The value of spermatology in male reproductive toxicology: Do spermatologic examinations in fertility studies provide new and additional information relevant for safety assessment? Reprod Toxicol 11(2-3): 171-178.

25. Chandrasekar R, Sivagami B (2017) Indian medicinal plant with diuretic activity. Indo American Journal of Pharmaceutical Research 7(1): 7359-7380. 